\title{
sciendo
}

DOI. 10.2478/anpm-2019-0008

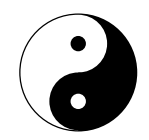

\section{IRANIAN BLUE-AND-WHITE CERAMIC JAR}

\author{
Jindřich Mleziva ${ }^{1}$
}

\begin{abstract}
Museum collections often contain items that are inaccurately, or even wrongly, identified. This was the case of a jar belonging to a collection in the West Bohemian Museum in Pilsen. The Iranian jar was apparently acquired at the end of the $19^{\text {th }}$ century and later mistakenly placed in the Chinese collection. This piece shows an interesting example of the evolution of Iranian pottery, but also of the history of the decorative arts collection in the Pilsen museum.
\end{abstract}

KEY WORDS: Iranian ceramics - Safavid Dynasty (1501-1736) - Qajar Dynasty (17851925) - museum collections - West Bohemian Museum in Pilsen - Josef Škorpil (18561931)

Origin: Iran, $17^{\text {th }}$ century (ceramic jar) $-19^{\text {th }}$ century (brass fittings)

Material: Stonepaste, ${ }^{2}$ underglaze painting, engraved brass fittings

Dimensions: Height: $16.7 \mathrm{~cm}$, Width: $17 \mathrm{~cm}$

Inventory number: $\mathrm{O} / 55$

Acquired: Apparently purchased in 1889 at the World Exhibition in Paris

\section{Introduction}

Items which have not been definitively categorized on the basis of region, date or typology are often found in museum collections, and often still await a more detailed and accurate analysis. This was also true in the case of the jar discussed here. The decorative arts department of the West Bohemian Museum in Pilsen manages a wide collection of decorative arts that was established at the same time the museum was founded, in $1888 .{ }^{3}$ From the time that the collection was first created, it has always

1 Contact: Jindřich Mleziva, the curator of the collection of the Applied Art Department of the West Bohemian Museum in Pilsen; e-mail: jmleziva@zcm.cz. The author would like to thank PhDr. Dagmar Pospíšilová, CSc. and Mgr. Adriana Stříbrná for help and comments on the subject of the article.

2 The material indicated is thought to be stonepaste on the basis of visual and comparative assessment; it has not been verified by chemical analysis.

3 The museum was founded when the Pilsen City Museum (est. 1878) was divided into two branches: the West Bohemian Museum of Decorative Arts, and the City Museum of History.

This work is licensed under the Creative Commons Attribution-Noncommercial-No Devivs 3.0 License 
contained items from the Near and Far East. Though the Far East portion of the collection included many ceramic items, the Near East portion of the collection includes only a few. In 1948, after the Second World War, the Museum of Decorative Arts was combined with other museums in Pilsen to form an institution that came to be called the West Bohemian Museum in Pilsen, and it remains so to this day. The decorative arts collection became one of the sub-collections of the new museum, from which the socalled oriental sub-collection was created in 1970s. This collection primarily contains items from China and Japan, but also some items representing applied arts from Near East countries, as well as India. Today, this blue-and-white ceramic jar with brass fittings, initially thought to be of Chinese origins, is also a part of this collection. Its shape and style of decoration is reminiscent of Chinese blue-and-white porcelain. However, this jar is originally from Iran, and was most likely made during the Safavid Dynasty (1501-1736), though the engraved brass fittings are a later addition, and were most likely added during the Qajar Dynasty (1785-1925). Chinese blue-and-white pottery was very popular in Iran, similarly as in Egypt, Syria and Turkey, which was evident by the products made in workshops in Damascus, Iznik, Kerman or Mashad. Efforts to match the quality of Chinese porcelain led to the development of stonepaste, which was similar to Chinese porcelain in terms of appearance and properties.

The jar was added to the museum's collection as a "Persian" piece, most likely in 1889 , and was re-categorized as part of the Chinese collection during the 1970s. The exact date when it was re-categorized is not known. The jar's origins were reviewed during a recent activity focusing on the museum's Near East collection, ${ }^{4}$ and in conjunction with the opening of a new permanent decorative arts exhibition in the West Bohemian Museum in 2017.

\section{Description of the Jar}

The jar is a low container, reminiscent of Chinese guan shape. It stands on a foot-ring, from which a bulbous body rises. The widest part of the container is the upper third. Closer to the container's neck, which is cylindrically shaped, the container markedly narrows. The neck is adorned with brass fittings, the outer sides of which are decorated with engravings. The entire surface of the container, excluding the bottom, is decorated with cobalt blue-and-black paintings of various geometric, floral, plant, and figural motifs. The jar is covered in a clear glaze both on the inner and outer sides, though the inside of the jar is not painted. The bottom of the jar is neither painted, nor glazed, and there are no marks. There are two larger cracks at the top of the body, and the glaze inside is cracked across the surface. One side of the foot-ring is heavily chipped. The jar's shape and composition of the cobalt blue painted decor is similar to jars massproduced in Chinese ceramic workshops during the Yuan (1271-1368) and Ming (13681644) dynasties. The bottom half of the jar is painted with a wavy floral border that is reminiscent of a simplified version of the peony borders that Chinese porcelain was often decorated with. The bottom of the motif is bordered with a loosely sketched blue double line, while a black double line borders the top of the motif. No other decorations on the jar are painted in black. The main motif is a figure of a lion moving from right to left, its jaws open, and the tail curled into an "s" shape. The lion is a favourite Iranian

4 See Mleziva 2017. 
symbol, and was associated with royal majesty and a powerful state. ${ }^{5}$ The lion was considered to be the king of all beasts, ${ }^{6}$ a majestic creature. Since ancient times, only the ruler was allowed the privilege of hunting lions. We can see scenes depicting lion hunts on hammered silver containers from the Sasanian Empire (224-651). Ancient depictions from the times of the Achaemenid Empire $\left(6^{\text {th }}\right.$ century -330 BC) or the Sasanians inspired Iranian artists of later times, all the way up until the $19^{\text {th }}$ century. The symbol of the lion is also associated with faith and religion. ${ }^{7}$ You can find lions on various types of objects; they are often depicted in battles, or while hunting, along with other animals or imaginary beasts. The depiction of the lion on this container bears only a slight resemblance to the mythical lion (qilin) found on Chinese porcelain. There are many other lions on Iranian pottery that more closely resemble the Chinese representation of this great hunter. ${ }^{8}$ The style of illustration on this particular jar is rather a combination of traditional, naturalistic renderings according to ancient Iranian styles, and composition based on the decoration of Chinese ceramics. One can find lions, or the mythical qilins that were intended to relate to Buddhist tradition, therefore, having different symbolism than that used in Iran. The rendering of the lion found on the Pilsen jar more closely resembles the depictions used in Iran [Fig.5]. There is a similar lion on a plate made in Qazvin, dated around 1570, which is part of the Royal Ontario Museum's collection (Object number: 998.40.1); that lion is, however, outlined in black.

Admiration for Chinese ceramics, and in particular porcelain, led to the use of materials that resembled the quality and appearance of porcelain. Above all, the use of similar decorations was common. ${ }^{9}$ The popularity of Chinese porcelain at the royal court, as well as in high society, led to an increased production of items imitating this type of porcelain in the local workshops. Production of items most similar to Chinese porcelain happened in Iranian workshops primarily during the Safavid period, as seen, for example, in a storage jar dated between 1630-1670 which is part of the Victoria and Albert Museum collection (Museum no. 1544-1903), or in 17th century plate that is a part of the Ashmolean Museum's collection (Accession no. EA1978.1784). However, items less similar to this style were also produced, and bore only a distant resemblance to their Chinese counterparts. These items still demonstrate the fondness for blue-andwhite porcelain and Chinese decoration, but do not replicate the styles so precisely; they had more in common with the local Iranian styles.

Apart from the main motif of the lion, the jar in question is also decorated with floral, plant and geometric motifs, and birds. The floral, plant and geometric motifs are presumably derived from Chinese patterns, though it is not always easy to identify a specific design. There are bunches of lotus flowers or peonies, plum tree motifs or mushrooms of eternal life. On the other side, one can see a honeycomb motif that is comprised of three parts. The top, right-hand side sprouts bunches of flowers and leaves. Two birds stand on the left side. The top part shows a motif reminiscent of the Chinese infinite pearl, bordered by a trapezoidal shape. The top part of the vase's body

5 The lion together with the sun became Iran's state symbol.

6 The lion is also presented as a king in, for example, Kalila wa-Dmina, a collection of fables which originated from the Indian Panchatantra.

7 Caliph Ali, an essential figure in Shia Islam, was a relation of the prophet Muhammad, who called him Asadullah - Lion of God.

8 See, for example, Dish, Iran, 1630-60, Victoria and Albert Museum, Museum number: 887-1976.

9 Celadon pottery was also very popular, and also often emulated. 
is edged by a row of leaves that are similar to a simplified version of a repeated cloverleaf motif, which often appears on the edges of Chinese porcelain containers. ${ }^{10}$

The neck of the jar is covered in brass work, the outer side of which is decorated by engravings with blackened lines. The figural decoration corresponds with the usual style of decorative brass work, during the rule of the Qajar dynasty in the $19^{\text {th }}$ century. The bottom edge of the brass fitting is engraved with a foliage scrolls; a popular metalwork decoration during the Safavid period. The figural decorations at both the top and bottom of the fittings are bordered by a repetitive diamond pattern. There are depictions of animals, people and mythical creatures. One can see scenes such as a lion attacking its prey, elephants adorned with gear, a lion hunting deer, birds, a dragon with a serpent's body and contemplative anthropomorphic creatures.

\section{The Origins of the Jar in Historical Context}

Traders most likely brought Chinese porcelain and ceramics to the Near East during the first Islamic dynasties, and they gradually became a valuable commodity for bringing to the West. The popularity of porcelain and its designs significantly influenced the historical development of Near East ceramics. The emulation of Chinese porcelain did not pertain only to the design, but also to the materials used in production. There is evidence dating to the $11^{\text {th }}$ century that a new material, whose properties were very similar to those of porcelain, began to be used. ${ }^{11}$ The stonepaste mentioned in Abü'lQāsim's Treatise on Ceramics has a high percentage of silica content (up to 80\%), about $10 \%$ of glass frit, and only $10 \%$ of clay, ${ }^{12}$ and became very popular in the production of ceramics around the eastern parts of the Mediterranean and Iran over the ensuing centuries. There were also forays into painting with cobalt blue under translucent glaze. Porcelain production increased for the purpose of export during the Yuan (1271-1368) and Ming (1368-1644) dynasties. Blue-and-white porcelain found its way to Egypt, Syria and Iran in large quantities during the $14^{\text {th }}$ and $15^{\text {th }}$ centuries. It became a significant trade item, was used for giving diplomatic gifts, or valued as spoils of war. From the $15^{\text {th }}$ century, Europeans entered into sea-trade with goods from China, starting with the Portuguese, who occupied the island of Hormuz as a main seaport and transit centre for the trading of goods from 1507. In 1622 the Portuguese were forced aside by the Safavids with the support of the English, and the trade centre was moved to the more easily protected port city of Bandar Abbas (earlier known as Gombroom) on the mainland. Regional trade was controlled by the English East India Company and the Dutch East India Company (Golombek 2014: 24-25). During this time, Chinese porcelain production was geared towards not only the European market, but also the Near Eastern market. However, Iran was not just a mere middleman in the business, because there was a high demand for Chinese porcelain among the upper classes (an example of this is the porcelain collection donated to the Ardabil Shrine by Shah Abbas the Great). ${ }^{13}$ These porcelain items inspired the production of ceramics resembling the Chinese blue-and-white pieces in Iran and other countries, ${ }^{14}$ though they were made of

\footnotetext{
10 Thanks to Mgr. Helena Heroldová, Ph.D. for help with the identification of some motifs.

11 See Mason 1995: 5-6.

12 Allan 1973.

13 See Pope 1956.

${ }^{14}$ Early pieces were made in workshops in Iznik.
} 
a different material (stonepaste). These items were true to the shape and decoration of their Chinese counterparts, and were sought after by the royal courts, as well as by the aristocracy. During this same period, imitations of a lower quality were also created. This was evident mainly in the quality of the decoration. Replicas of Chinese ceramics that were produced for the lower classes had decorations that were not as intricate or true to the originals (Golombek 2014: 21-22). The fall of the Ming dynasty and earlier eras that led to the Qing dynasty's (1644-1911) rise to power caused a fall in production and export of porcelain. This lack of Chinese export meant that there was a greater demand on production in workshops outside of China that were producing replicas of the Chinese ceramics, and for a short time, they then filled the gap that had been created in the market. Ceramic workshops in Japan or Iran are mentioned in this context (Golombek 2014: 109). Production in the emperor's workshops in Jingdezhen was renewed in 1683 and led to the end of the transitional era.

Many of the Chinese replicas produced in Iranian workshops were not used as they were traditionally intended to be. Many of these became decorative objects, or were altered to fit the needs of the local community. One such example are containers known as kendi. Its original purpose was like that of a kundika (from sanskrit), a pouring vessel, and it came from ancient India and was later used over the greater part of Asia. They were produced out of porcelain in China and were exported to the West. ${ }^{15}$ These types of containers were used as decorative pieces, or were adapted for use as, for example; ewers, such as the case in Europe. In the Near East, they were used as water pipes because of their size, shape, and the fact they had two openings that suited them for this. Often, the containers were adapted using metal fittings that were attached to the ceramic body. Similarly as kendis were used for making water pipes in Iran, other types of porcelain containers were also adapted with metal fittings (often bronze, but other metals, for example, silver, were also used) for other uses, or were used as decorative objects in European homes. The use of bronze fittings on Asian porcelain products was still very popular in Europe during the $19^{\text {th }}$ century. The Pilsen jar, as well as other examples of Iranian ceramics found in European collections, ${ }^{16}$ provides evidence that similar adaptations and fittings were also used in the Near East. Though the Pilsen jar is similar in shape to metal or ceramic vases from the Near East, this particular version was modelled according to the Chinese guan shape. The hammered brass metal fittings were added later. The engraving and stamps are only seen on the outer side of the neck. The depicted figures and the style in which they are done are typically seen on brass pieces made in Iran during the Qajar dynasty. Depictions of realistic as well as imaginary figures of people and animals were inspired by religious texts (for example, Solomon as the ruler of people and supernatural creatures, able to talk with animals and other creatures), ${ }^{17}$ or by richly illustrated medieval texts. ${ }^{18}$ The illustrations in these books

${ }^{15}$ Kendis are present in the oil paintings of the Dutch Masters, for example Peter Paul Rubens (15771640) with Jan Brueghel the Elder (1568-1625) and their work, "The Sense of Sight," (1617, Museo del Prado, Inventory number P001394) or (with metal fittings) in "Nature Morte," by Pieter Gerritsz van Roestraten (1630-1700) (private collection).

${ }^{16}$ Ewer with brass mounting, Iran, 1630-60, 1800-70 mounting, Victoria \& Albert Museum, Museum number: 467-1874.

17 Quran 27:16-17.

18 Rich illustrations were part of Ferdousi's (ca 940-1020) Shahnameh (Book of Kings), Nizami's (1141-1209) Khamsa (Quintet). The illustrations in these books were often used as inspiration for the decoration of ceramic or metal items. 
were often used as inspiration for the decoration of ceramic or metal items. Brass items from the $19^{\text {th }}$ century are decorated with analogous engravings or openwork. These objects are usually pouring vessels, bowls, incense burners or trays. One can repeatedly see the use of popular animals, imaginary beasts or mythological figures in the decoration of these items [Fig. 6].

\section{Origins of the Jar}

According to later inventory notes, the jar was bought from the H. Saenger Company in Hamburg, though the exact date of acquisition is missing. ${ }^{19}$ No archival notes have been found that would further confirm this acquisition. According to archival notes, Josef Škorpil (1856-1931), the director of West Bohemian Museum of Decorative Arts, bought many items from the Hamburg based H. Saenger Company between the beginnings of the $20^{\text {th }}$ century approximately until the beginning of the First World War. The company specialized in antiques from China and Japan. ${ }^{20}$ During this period, much of the West Bohemian Museum of Decorative Arts' oriental sub-collection, which focused mainly on arts and crafts from China and Japan, was established. The regional museum acquired a significant portion of representations of Asian art for the decorative arts collection in this way, which was typical for any superior-quality decorative museum collections established during this period. ${ }^{21}$ The H. Saenger Company apparently also did business with other institutions in Czech lands, as indicated by its correspondence with Josef Škorpil, where Škorpil recommends the institutions as potential clients. ${ }^{22}$

Records from the new inventory book started in the 1970's describe the jar as a Chinese "sacrificial vase with blue décor" from the $16^{\text {th }}$ century. ${ }^{23}$ The jar is already described as being stoneware. Because the jar's original purchase documents from the H. Saenger Company have not been found, it is possible that it was actually acquired through different means, and that the descriptions and origins written were not accurate. ${ }^{24}$ A likely possibility is that the jar was bought along with several other items at the World Exposition in Paris in 1889. Josef Škorpil himself went to the exposition

19 The original purchase protocol relating to the jar has so far not been found in the archives. Though the purchase of items from the H. Saenger Company was usually documented, many items were acquired during this particular period, and the details of individual items, are sketchy, often being composed simply of the object's name, but with no mention of its description or cost.

${ }^{20}$ The company's letterhead from $6^{\text {th }}$ January 1909 states its name as: " $H$. Saenger, Hamburg. Import \& Lager von Japan- \& China- Waaren".

${ }^{21}$ The Museum of Decorative Arts in Liberec (1873), The Museum of Decorative Arts in Prague (1885), The Museum of Decorative Arts in Brno (1873) and the Imperial Royal Museum of Art and Industry in Vienna (1863) were all established during the second half of the $19^{\text {th }}$ century. The Viennese museum provided the standard according to which the other museums in Austro-Hungary were established, and worked in close connection with them. The Viennese museum itself was inspired by the South Kensington Museum in London (1852), which is today known as the Victoria and Albert Museum.

${ }^{22}$ Transcribed letter from Josef Škorpil of 23rd April 1903 to the H. Saenger Company. Archive of the WBM in Pilsen, Book No. 54, year 1902-3.

${ }^{23}$ From the West Bohemian Museum's decorative arts branch in Pilsen inventory book, Orient I. O/11221 , p. 22-23.

${ }^{24}$ It would not be the first time something like that has happened. For example, a ewer from the West Bohemian Museum in Pilsen's collection, inv. no. UMP 16549, was later catalogued as being "Rhodes-Persian", though the original purchase documents describe it as being made by a French company named Samson. For more, see Mleziva 2016. 
and bought a number of pieces from various vendors for the decorative arts collection. Apart from different representations of European arts and crafts, he also purchased items from the Near East, including ceramics that were from Damascus, ${ }^{25}$ which were described as "Rhodes-Persian". ${ }^{26}$ Two descriptions (in particular) suggest that they may be referring to this jar. However, the individual descriptions are so sparsely written, that it is impossible to confirm with certainty that this is actually the case. The most likely explanation is that it was purchased at the World Exposition from the Commission General de la Perse, where records of a "faience vase, blue decoration, Persian" had been kept. The brief description does not mention brass fittings, but there are no other vases in the museum collection that would otherwise fit this description. ${ }^{27}$

\section{Conclusion}

The jar's history is not limited only to its origins, but it continues on within the collection of the West Bohemian Museum in Pilsen. The collection was systematically developed from the end of the $19^{\text {th }}$ century, and went on to become one of the most significant decorative arts collections in the region. Josef Škorpil concentrated not only on creating a representative collection of regional decorative and fine arts, but, inspired by museums such as Vienna's Imperial Royal Museum of Art and Industry and London's South Kensington Museum (Victoria and Albert Museum), he created a collection which also displays a European selection of arts and crafts. Similarly as other institutions of the time, he also included pieces that represented Asian decorative and fine arts. He was able to do this thanks to a rich resource of contacts and connections with significant artists and businessmen of the time, and also thanks to the generous funding provided by the city of Pilsen. Because of this, Škorpil was able to supplement the collection with a range and quality of artefacts that a regional museum would not be able to acquire today. Under the influence of political change, the collection underwent a complicated evolution during the $20^{\text {th }}$ century. When a new oriental sub-collection was created during the 1970's, items from the Near East and India did not receive the attention they deserved. Only certain selected items were included in the sub-collection. Because of a lack of professional understanding of the material, many items were catalogued vaguely, or incorrectly. The jar was described as being of Chinese origin, without any further investigation of its painted décor, brass fittings, or how it was originally acquired. Near Eastern ceramics have only a small representation in the collection, meaning that this jar is an important example of the development of ceramics in that particular region, also bearing in mind the presence of exported blue-and-white porcelain from the $17^{\text {th }}$ and $18^{\text {th }}$ century in the collection. Another example of Iranian blue-and-white ceramics, this time from the $19^{\text {th }}$ century is a bowl whose decoration

${ }_{25}$ Two 4-part series of tiles were also purchased at the exhibition.

26 "The Rhodes-Persian" faience, as it is called in the Czech descriptions, also known as "Rhodian ware" often labeled Ottoman or Safavid ceramics in the $19^{\text {th }}$ century. The name "Rhodian ware" is often associated with significant findings of ceramic items originally from Turkish workshops in Iznik from the $16^{\text {th }}$ and $17^{\text {th }}$ centuries. In the $19^{\text {th }}$ century, they were then thought to be manufactured in workshops on the island of Rhodos. The origin of this assumption came from French photographer and archaeologist Auguste Salzmann (1824-1872) (for more information, see Atasoy and Raby 1989: 71-72).

27 The vase was originally entered into the inventory ledger under the number 2711, and has not yet been identified with the item under the current inventory number. 
somewhat resembles that of Chinese porcelain (inv. no. O/144) [Fig. 7]. It was purchased in 1911 from Ludwig Glenk, an antiques dealer in Berlin. The inventory from the 1970's once again describes this piece as being Chinese, though it is described as "Persian" in the archival purchase registry. ${ }^{28}$ We can also mention another Iranian jar decorated with a blue-and-white floral motif (inv. no. A 483) [Fig. 8] that is a part of the Náprstek Museum of Asian, African and American Culture's collection. This piece, however, does not have any metal fittings. Similar items may be found in other collections throughout the Czech Republic, but these are nevertheless still outside the range of interests of some would-be researchers. Blue-and-white ceramics are still popular in Iran to this day. An example of Iranian handicraft work produced in regional workshops at the beginning of the $20^{\text {th }}$ century is a set of dishes recently purchased by the Náprstek Museum (inv. nos. A31511-A31517) [Fig. 9].

\section{Literature:}

\section{Adey, Elizabeth June}

1994 A study of the iconography of the lion in Islamic art [online]. Edinburgh. Thesis. University of Edinburgh [cit. 2018-09-17]. Available at https://www.era.lib.ed.ac.uk/ handle/1842/17580;

Allan, James W.

1973 Abū'l-Qāsim's Treatise on Ceramics. In: Iran. London: British Institute of Persian Studies, (Vol. 11), pp. 111-120;

\section{Allan, James W.}

1991 Islamic Ceramics. Oxford: Ashmolean Museum, 1991. ISBN 18-544-4001-2;

\section{Atasoy, Nurhan - Raby, Julian}

1989 Iznik: the pottery of Ottoman Turkey. London: Alexandria Press;

Frýda, František, ed.

2008 Západočeské muzeum v Plzni 1878-2008: West Bohemian Museum in Pilsen = Das Westböhmische Museum in Pilsen. Plzeň: Západočeské muzeum v Plzni;

Golombek, Lisa - Mason, Robert B. - Proctor, Patricia - Reilly, Eileen

2014 Persian Pottery in the First Global Age. The Sixteenth and Seventeenth Centuries. Leiden: Brill, 2014. ISBN 978-90-04-26092-4;

\section{Mason, Robert B.}

1995 New Looks at Old Pots: Results of Recent Multidisciplinary Studies of Glazed Ceramics from the Islamic World. In: Muqarnas. Leiden: Brill, Vol. 12, pp. 1-10;

\section{Mleziva, Jindřich}

2016 Iznik or Paris? Imitations of Ottoman Pottery in the Collection of the West Bohemian Museum in Pilsen. In: Annals of the Náprstek Museum. Prague: National Museum, Volume 37: Issue 1, pp. 33-40. ISSN 0231-844X;

\section{Mleziva, Jindřich}

2017 Umělecké řmeslo Blízkého východu ve sbírce Západočeského muzea v Plzni. Plzeň: Západočeské muzeum v Plzni. ISBN 978-80-7247-141-6;

28 "Pers. schale transpar.", with the addition of the décor's color and its dimensions. The purchase records from 23. 8. 1911, Archives of the WBM, purchase document no. 85. Ludwig Glenk specialized in dealing with Asian antiques. 


\section{Pope, John Alexander}

1956 Chinese porcelains from the Ardebil shrine. Washington: Smithsonian Institution, Freer Gallery of Art, 1956. Publication (Smithsonian Institution);

2003 Tulipán v lesku půlměsíce: turecká keramika 15.-17. století a její ohlasy v Evropě : 5. řína 2003 - 8. února 2004 [Sbírka orientálního umění], Zámek Zbraslav: [katalog výstavy]. Praha: Národní galerie. ISBN 80-703-5275-2.
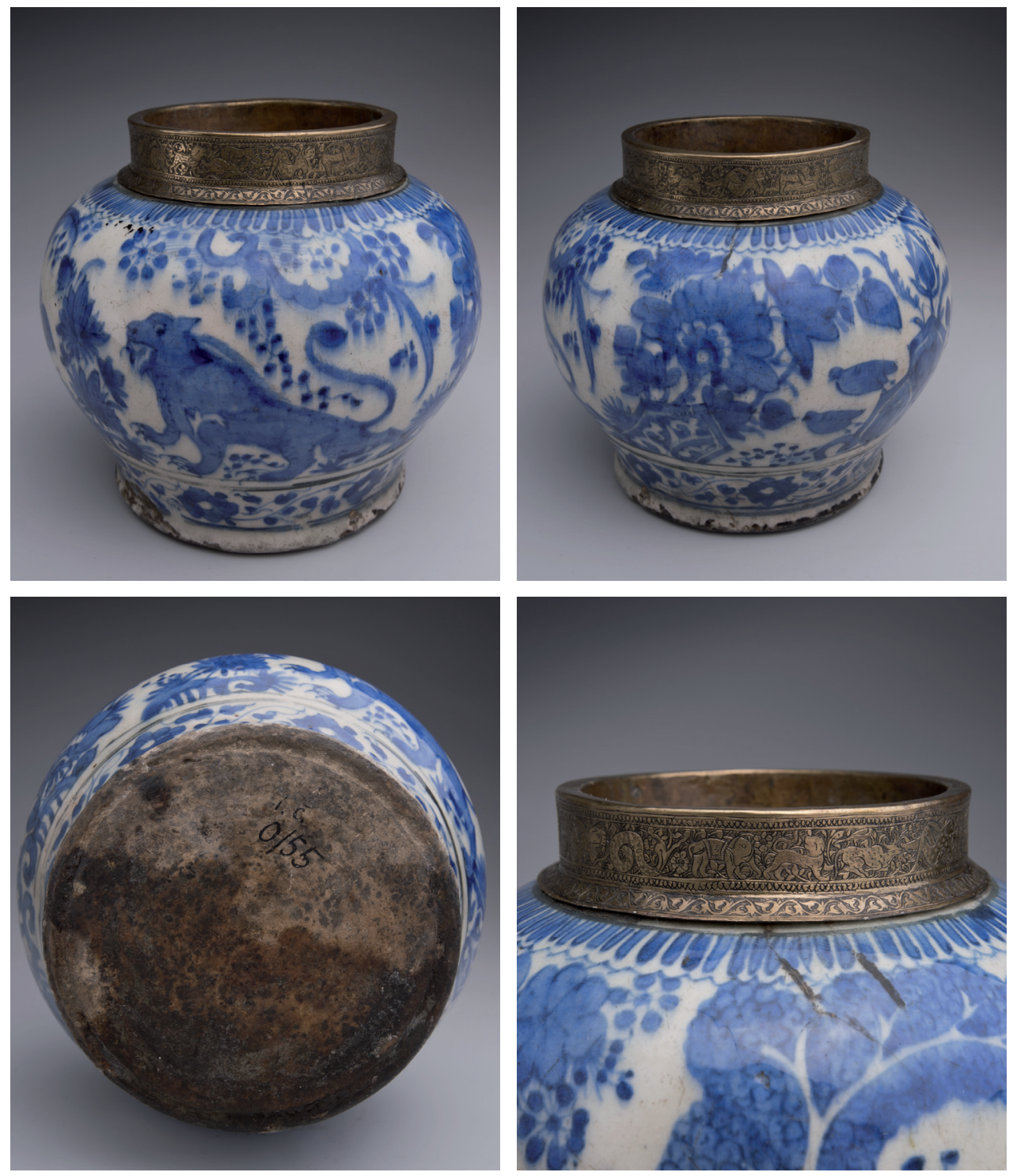

Fig. 1-4 Jar. Iran, $17^{\text {th }}$ century (jar) $-19^{\text {th }}$ century (brass fittings). Stonepaste, underglaze painting, engraved brass fittings. Height: $16.7 \mathrm{~cm}$, Width: $17 \mathrm{~cm}$. Inv. No. O/55. The West Bohemian Museum in Pilsen. (Photo: Václav Marian) 


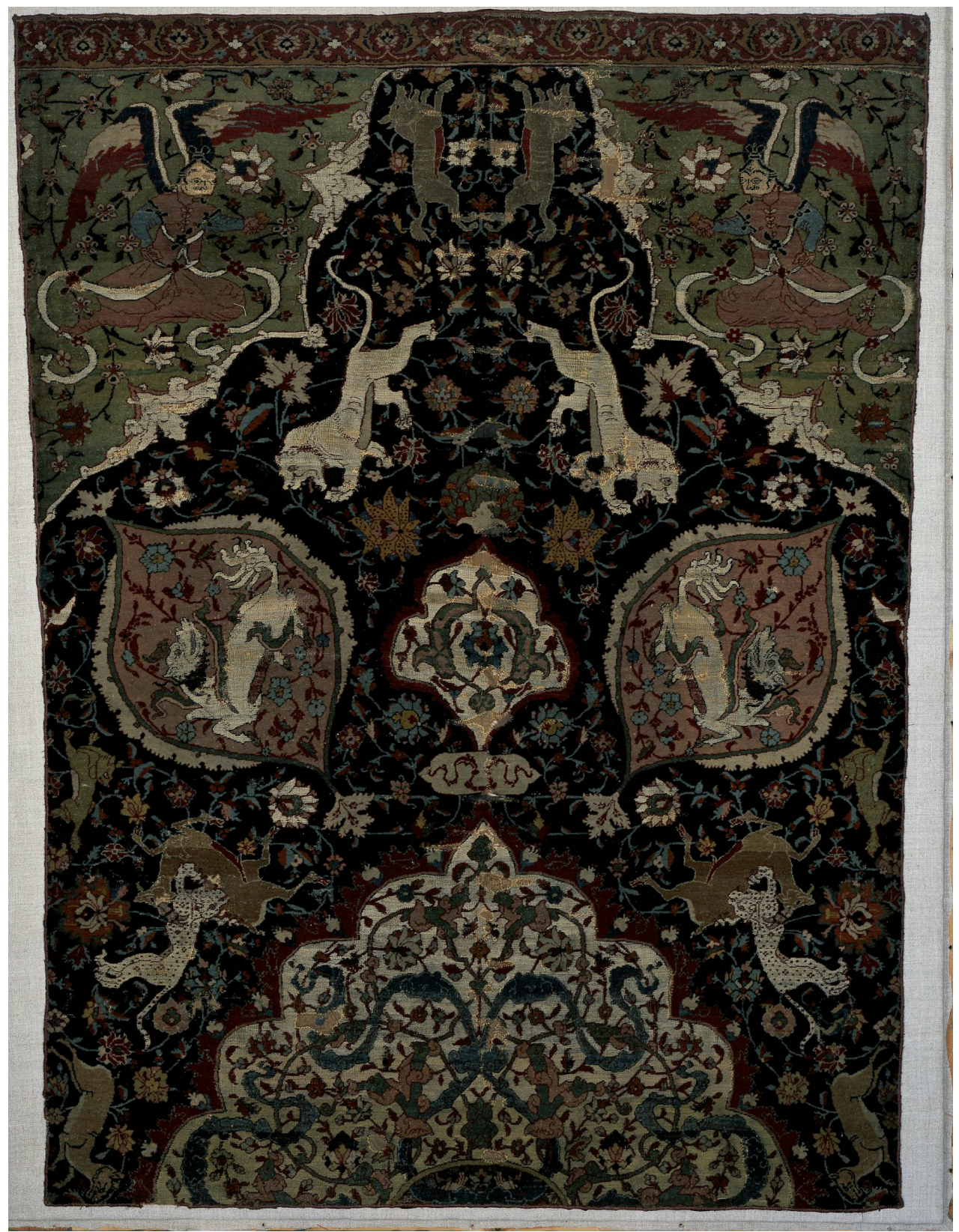

Fig. 5 Carpet. Iran, 1525-1550. Hand-knotted woollen pile on silk warp and weft, with brocade metal thread; asymmetrical knot, open to the left; 7,744 per sq. dm. Length: $139 \mathrm{~cm}$, Width: $105.5 \mathrm{~cm}$. Museum number: T.77-1919. (C) Victoria and Albert Museum, London. 


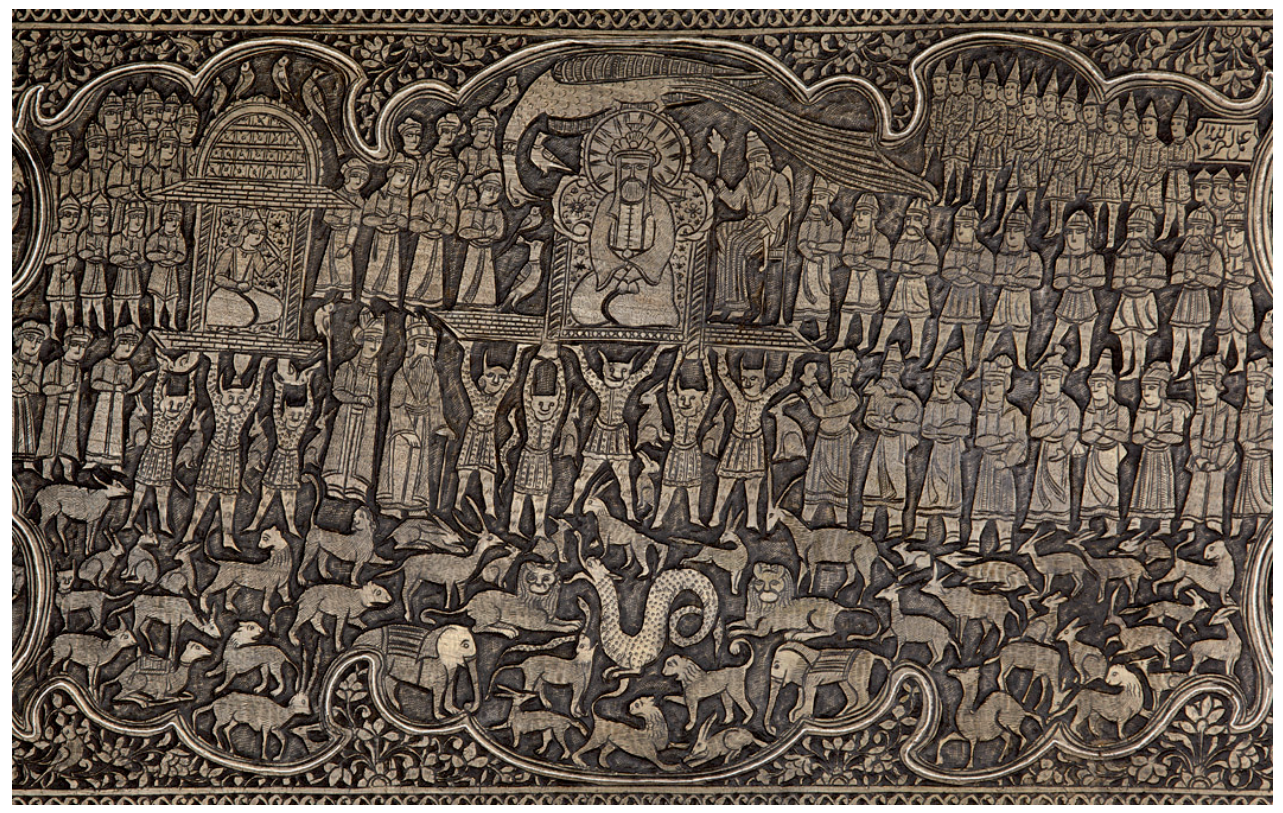

Fig. 6 Tray. King Solomon and Queen of Sheba (detail). Iran, 19 ${ }^{\text {th }}$ century. Hammered and engraved brass, inlaid with silver. Length: 88.7, Width: $58.8 \mathrm{~cm}$. Inv. no. A2911. NM - Náprstek Museum. (Photo: Jiří Vaněk)

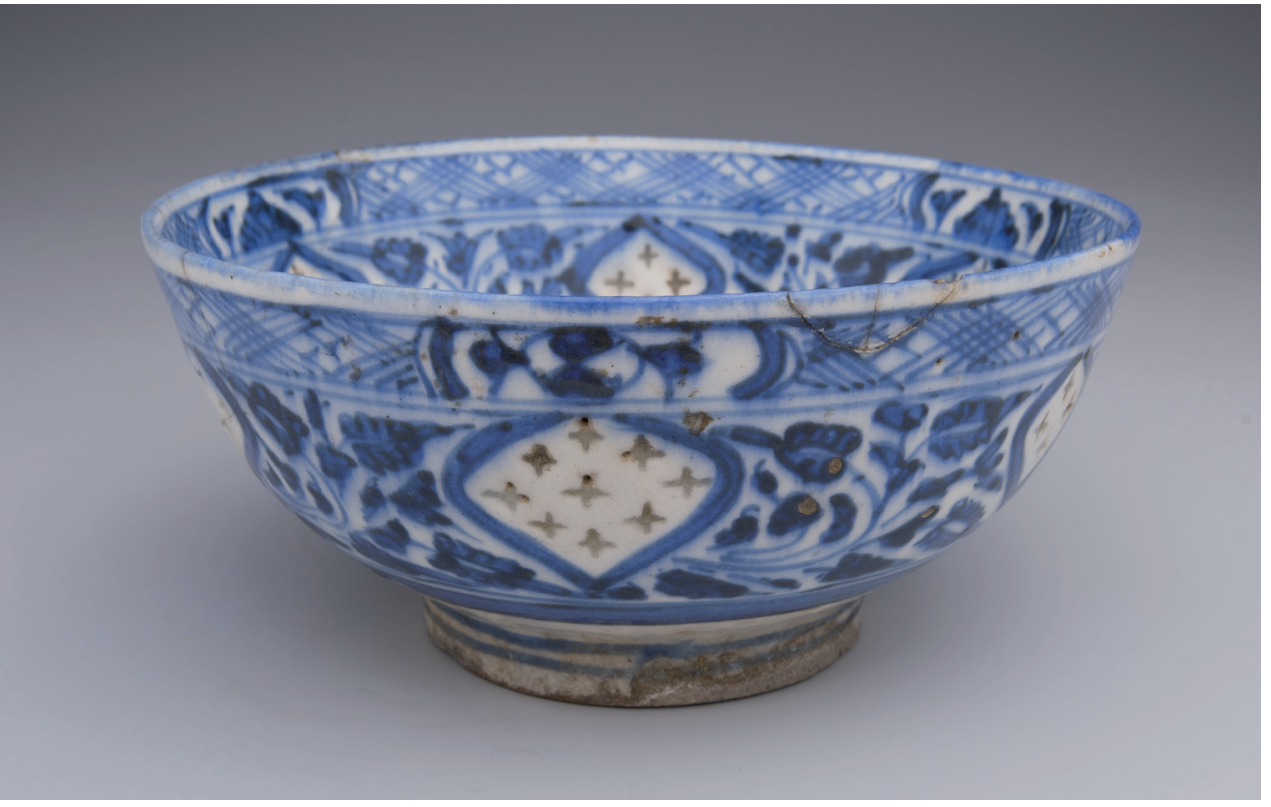

Fig. 7 Bowl. Iran, $19^{\text {th }}$ century. Stonepaste (?) with underglaze painting. Diameter: $18 \mathrm{~cm}$, Height: $8.5 \mathrm{~cm}$. Inv. no. O/144. The West Bohemian Museum in Pilsen. (Photo: Václav Marian) 


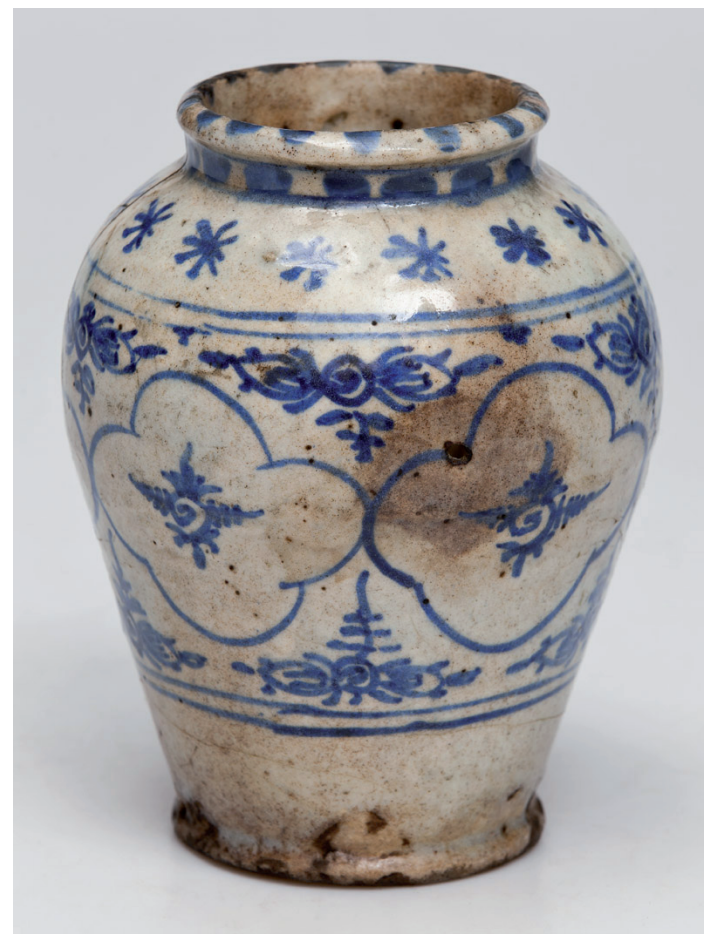

Fig. 8 Jar. Iran, $17^{\text {th }}-18^{\text {th }}$ century. Stonepaste (?) with underglaze painting. Height: 20 cm, Diameter: 17 cm. Inv. no. A483. NM - Náprstek Museum. (Photo: Jiří Vaněk)

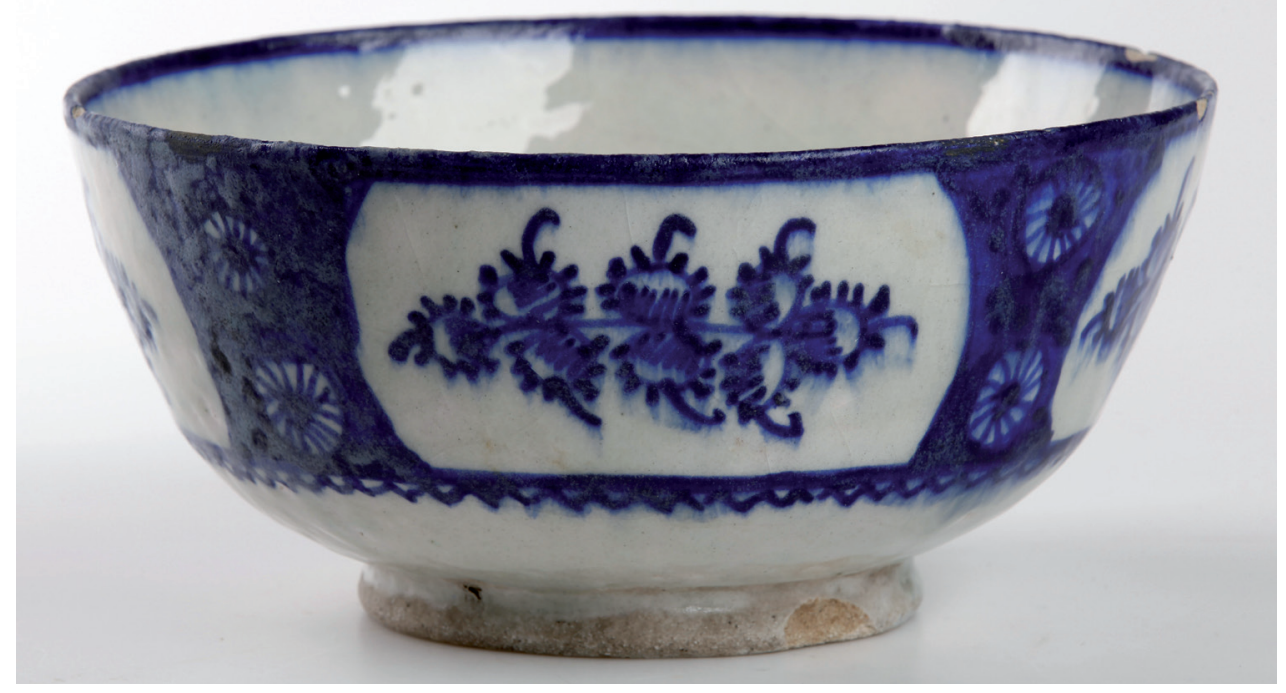

Fig. 9 Bowl. Iran (probably Kashan), early $20^{\text {th }}$ century. Stonepaste (?) with underglaze painting. Diameter: 23 cm, Height: 11.2 cm. Inv. no. A31514. NM - Náprstek Museum. (Photo: Jiří Vaněk) 